FIU Law Review

Spring 2010

\title{
Rebuilding the Board: An Argument for Structural Change, Over Policy Prescriptions, at the NLRB
}

\author{
R. Alexander Acosta \\ Dean of the Florida International University College of Law
}

Follow this and additional works at: https://ecollections.law.fiu.edu/lawreview

Part of the Other Law Commons

Online ISSN: 2643-7759

\section{Recommended Citation}

R. Alexander Acosta, Rebuilding the Board: An Argument for Structural Change, Over Policy Prescriptions, at the NLRB, 5 FIU L. Rev. 347 (2010).

DOI: https://dx.doi.org/10.25148/lawrev.5.2.7

This Article is brought to you for free and open access by eCollections. It has been accepted for inclusion in FIU Law Review by an authorized editor of eCollections. For more information, please contact lisdavis@fiu.edu. 


\title{
Rebuilding the Board: An Argument for Structural Change, Over Policy Prescriptions, at the NLRB
}

\author{
R. Alexander Acosta*
}

Whither the Board, the title of this symposium, is an obvious pun. The Board's relevance appears to be diminishing, and its future appears uncertain. These twin themes are not new to labor law scholars and practitioners, as the extensive scholarship on these issues makes clear. Despite decades of critical scholarship, however, the Board remains resistant to change and thus remains in a slow, withering decline.

My lunch remarks today offer a perspective that is in many ways unusual. I served on the Board for a short time; yet unlike many of my Board colleagues, I did not arrive at the Board with a strong tradition of representing labor or management. I now serve in the legal academy; yet unlike many of my present colleagues, I have experienced first-hand the internal dynamics of the Board. I hope my perspective offers new and useful insight into why the Board resists change, and perhaps helps encourage a future Board to take on this challenge.

My conclusion, in the end, presents a challenge to scholars and Board Members alike. Although scholars have repeatedly identified problems with the operation of the Board and crafted creative and practical solutions to address these problems, the Board has routinely ignored scholarly suggestions. The reasons for this resistance to change are not based on policy, and in fact several Chairmen - from Gould to Liebman - would agree that many of these suggested changes would as a matter of policy benefit the Board. The reasons that change has not occurred, rather, flow from the Board's internal operational structure, developed over time in response to a variety of factors including confirmation politics. This suggests that improvements in the operations of the Board should focus on structure rather than policy. One major change would be to adopt quasi-legislative rule-

\footnotetext{
* R. Alexander Acosta is the Dean of the Florida International University College of Law and former member of the National Labor Relations Board, where he participated in or authored more than 125 opinions. Prior to joining FIU, he served as the U.S. Attorney for the Southern District of Florida and as the Assistant Attorney General (Civil Rights) at the Department of Justice. He graduated from Harvard College and the Harvard Law School. This article is the publication of Dean Acosta's lunch remarks at FIU Law Review's Whither the Board Symposium on March 26, 2010.
} 
making as opposed to quasi-judicial case-by-case adjudication as a means of issuing major policy changes. The challenge for scholars and Board Members alike is to not again enumerate the advantages of rulemaking or other proposed solutions, but rather to help develop internal Board structures that better allow the Board to adopt this and other proposed changes. Structural change, I believe, is necessary to reverse the Board's withering decline.

I begin with some basic observations.

First, the NLRB's practical relevance is in decline. Scholars have noted this. Indeed, current NLRB Chairman Wilma Liebman ${ }^{1}$ titled her 2007 essay on the Board "Decline and Disenchantment," and cited dozens of scholars who concur in this assessment of the Board's relevance. ${ }^{2}$ Empirical evidence further supports this observation. Representation and unfair labor practice case intake, for example, has declined by more than one third in the past ten years. ${ }^{3}$

The best evidence of decline, perhaps, is the fact that the five-member NLRB operated with only two Members, without a quorum, from December 31, 2007 to April 5, 2010. ${ }^{4}$ Media coverage of this arguable crisis at the Board was quite limited, and legislators seemed unconcerned, as nominees

1 Chairman Liebman has noted that the title Chairman should be non-gender specific.

2 See generally Wilma B. Liebman, Decline and Disenchantment: Reflections on the Aging of the National Labor Relations Board, 28 BERKELEY J. EMP. \& LAB. L. 569 (citing James J. Brudney, A Famous Victory: Collective Bargaining Protections and the Statutory Aging Process, 74 N.C. L. REV. 939 (1996); Cynthia Estlund, The Death of Labor Law?, 2 ANN. REV. L. \& Soc. ScI. (2006); Harry Sangerman, NLRB: DOA?, 33 EMP. REL. L. J. 74 (2007); Benjamin I. Sachs, Labor Law Renewal, 1 HARV. L. \& PoL'Y R. 375 (2007); Michel H. Gottesman, In Despair, Starting Over: Imagining a Labor Law for Unorganized Workers, 69 CHI.-Kent L. REV. 59 (1993); James J. Brudney, Isolated and Politicized: The NLRB's Uncertain Future, 26 COMP. LAB. L. \& POL'Y J. 221 (2005); Julius Getman, The National Labor Relations Act: What Went Wrong; Can We Fix It?, 45 B.C.L. Rev. 125 (2003)).

3 Liebman, supra note 2, at $571 \mathrm{n} .13$ ("The Board's representation case intake has declined by 26\% from 2005 to 2006. From 1997 to 2007, it declined by 41\%. During that same ten-year period, unfair labor practice case intake declined by $31 \%$.") (citing BNA DAILY LABOR REPORT, Board Inventory Lowest in Decades, Jan. 17, 2007, at S9). NLRB representation case intake has since declined. See 72 NLRB ANN. REP. 10 (2007), available at http://www.nlrb.gov/shared_files/Annual_Reports/ NLRB2007.pdf (8.7\% decrease in FY2007 (from 3,637 to 3,318 petitions filed)); 73 NLRB ANN. REP. 11 (2008), available at http://www.nlrb.gov/shared_files/Annual_Reports/NLRB2008.pdf (slight 2.3\% increase in FY2008 (from 3,318 to 3,393 petitions filed)); 74 NLRB ANN. REP. 10 (2009), available at http://www.nlrb.gov/shared_files/Annual_Reports/NLRB2009.pdf (14.2\% decrease in FY2009 (3,393 to 2,912 petitions filed)).

4 About Us: Board, NLRB.gov, http://www.nlrb.gov/about_us/overview/board/index.aspx (last visited July 24, 2010). The NLRB now has five members: Chairman Wilma B. Liebman, who has served on the board since November 14, 1997; Peter Carey Schaumber, who has served on the board since March 19, 2008; Craig Becker, who was sworn in on April 5, 2010; Mark G. Pearce, who was sworn in on April 7, 2010; and Brian Hayes, who was sworn in on June 29, 2010. See generally id. 
languished in the Senate..$^{5}$ Other than labor lawyers, few even seem aware that the federal agency supposedly charged with enforcing the labor act was without authority to operate for twenty-seven months. Such near complete indifference about the Board's operational legitimacy speaks volumes about the status of the Board in modern labor policy.

My second point is that scholars and practitioners have offered again, and again, reasons and solutions for this decline. Though many of these solutions are sound, the Board has routinely ignored them.

A common criticism is that the caselaw oscillation, a.k.a. flip-flops, plagues Board law. As a matter of policy, these flip-flops reduce public and judicial confidence in the Board. In practice, this oscillation also reduces both management and labor's reliance on Board law because neither side is sure what the future will hold. ${ }^{6}$

5 In the one year period preceding April 2010, The Wall Street Journal, The New York Times, and The Washington Post only published three articles on the topic combined: Kris Maher \& Melanie Trottman, U.S. News: Union-Backed Nominee Is Blocked in Senate, WALL ST. J., Feb. 10, 2010, at A4 ("The nomination of union lawyer Craig Becker to the National Labor Relations Board fell short of the 60 votes needed to end a Republican filibuster Monday, with just 52 senators voting to support his appointment. Mr. Becker's defeat was a sharp setback for the big labor unions that championed his nomination. He was strongly opposed by business interests. . .."); Steven Greenhouse, Labor Panel Is Stalled by Dispute on Nominee, N.Y. TIMES, Jan. 15, 2010, at A16; Sheryl Gay Stolberg, Obama Bypasses Senate Process, Filling 15 Posts, N.Y. TIMES, March 28, 2010, at A1. Other articles were primarily featured in smaller newspapers or online blogs. See Sam Hananel, On Labor Day, Labor Board Still in Gridlock, Boston GloBe, Sept. 7, 2009, at 7; Thomas Ferraro, Republicans flex new power, block Obama nominee, REUTERS, Feb. 9, 2010, available at http://www.reuters.com/article/2010/02/09/ us-usa-congress-republicans-idUSTRE6185MT20100209 ("Obama, frustrated that Republicans have delayed votes on a number of his nominees, said on Tuesday he may make temporary 'recess appointments' during Congress's break next week. 'We can't afford to allow politics to stand in the way of a well-functioning government,' Obama declared. Recess appointees could stay in office until the end of next year. Republican and Democratic presidents have made such appointments, drawing outrage from the opposing party. Republican Senator Orrin Hatch urged Obama not to circumvent the Senate on Becker, saying, 'The Senate spoke with a loud, clear and bipartisan voice.' The Becker battle is part of a bigger fight - between organized labor and business, between Democrats and Republicans - over stalled legislation to make it easier to unionize."); Carter Wood, If a NLRB Quorum is So Important, Confirm Other Nominees, SHOPFLOOR BLOG, Feb. 19, 2010, available at http://shoopfloorblog.org2010/02/if-anlrb-quorum-is-so-important-confirm-other-nominees/11022; United State Senate Democratic Communications Center, Republicans Continue Blocking Qualified Nominees, U.S. Senate Documents, Feb. 8, 2010.

See Samuel Estreicher, Policy Oscillation at the Labor Board: A Plea for Rulemaking, 37 ADMIN. L. REV. 163, 163 (1985) ("The National Labor Relations Board (NLRB) has made the labor law professor's job a nightmare. A labor law professor's dream, like that of any other serious academic, is to deal with a relatively inert body of law, to be able to read the decisions and statutes once - and only once - and then work up a fairly decent set of notes which can be used year after year, leaving time for the more worthwhile pursuits of life. This federal agency simply won't let us be. These days the BNA labor service treats us to a reversal a week by the NLRB, sometimes coupled with notice that the Board has asked a court of appeals to remand a case to it for reconsideration. How is my tennis game to improve under these circumstances?"). 
Caselaw oscillation at the Board is not new. Consider, for example, whether a non-unionized workplace employee is entitled to have a coworker representative present during investigatory interviews. In 1982, the Board interpreted Section 7 to grant a right to representation. ${ }^{7}$ Then, in 1985, the Board reinterpreted Section 7 as not granting this right. ${ }^{8}$ In 2000, the Board reversed itself yet again, ruling this time in favor of representation. ${ }^{9}$ Four years later, in 2004, the Board flipped again, ruling once more that employees were not entitled to co-worker representation. ${ }^{10}$ Given this history, I predict that a Liebman Board is likely once again to flip the 2004 precedent.

The current scholarship critiquing flip-flops evokes a sense of déjà vu. Nearly ten years ago, in the summer of 2000, another of today's speakers, Andrew Kramer, complained of the Board's caselaw oscillation:

It is evident that the significant disagreements among the Board's current members are based on fundamental differences on the interpretation of the Act and who is entitled to the Act's protection. . . . These divisions have resulted in numerous 3-2 and 2-1 decisions and even led one Board member to jest that a 'day without a dissent is like a day without sunshine.' . . . [O]ne of the most troublesome issues surrounding the Board has been its willingness to challenge and change well established precedent. Such criticisms are not new [Kramer wrote 10 years ago]. Indeed, my objections on this point sound very similar to the comments made about the Board during the Reagan Administration. ${ }^{11}$

7 Materials Research Corp., 262 N.L.R.B. 1010, 1010 (1982) ("The General Counsel and the Charging Party except, contending that the Weingarten right to request the presence of a representative at an investigatory interview flows from the Section 7 right of employees to engage in concerted activity for mutual aid or protection, and does not depend upon the representational status of a particular group of employees. We agree.”).

8 Sears, Roebuck, \& Co., 274 N.L.R.B. 230, 230 (1985) ("Weingarten rights are inapplicable where, as in the case before us, there is no certified or recognized union. Pursuant to this view, we overrule the Board's contrary decision in Materials Research Corp., 262 N.L.R.B. 1010 (1982).”).

9 Epilepsy Found. of Ne. Ohio v. NLRB, 331 N.L.R.B. 676, 678 (2000) ("We disagree with the Board's holdings in Sears and Dupont, and find that a return to the rule set forth in Materials Research, i.e., that Weingarten rights are applicable in the nonunionized workplace as well as the unionized workplace, is warranted.").

10 In re IBM Corp., 341 N.L.R.B. 1288, 1288 (2004) ("[W]e have decided, for the reasons set forth below, to overrule Epilepsy Foundation and return to earlier Board precedent holding that the Weingarten right does not extend to a workplace where, as here, the employees are not represented by a union.").

11 Andrew M. Kramer, The Clinton Labor Board: Difficult Times for a Management Representative, 16 LAB. LAW. 75, 77-80 (Summer 2000) (citing NLRB Heads Into 2000 With Improved Budget, Full Board, New General Counsel, Daily LAB. REP. (B.N.A.) No. 6, Jan. 10, 2000, at S-5 (interview comment by Member Hurtgen)). 
One solution to reduce caselaw oscillation is increased reliance on rulemaking in lieu of adjudication. Although this solution has been repeatedly proposed, the Board has used rulemaking authority only rarely. ${ }^{12}$ As former Member Babson, who is here with us today, recalls, the last time the Board issued a rule was during his tenure, in 1989. Samuel Estreicher and Jeffrey Lubbers will elaborate on the value of rulemaking when they speak later today and tomorrow, so I will note only that courts and scholars consistently cite several advantages, including but not limited to:

- Predictability - Management, labor and employees would know which rules apply to their conduct, especially since rulemaking unlike caselaw, is entirely prospective. ${ }^{13}$

- Efficiency - A clear rule would allow early resolution of recurring issues, obviating the need for repeated Board consideration of similar fact patterns. ${ }^{14}$

- Stability - Although the rulemaking process is burdensome, once adopted, this same burdensome process makes a rule very difficult to change. ${ }^{15}$

- Judicial Deference - As Jeffrey Hirsch will discuss later today, it appears that Courts of Appeals devalue Board decisions. Appellate success would increase as greater deference is paid to rules. ${ }^{16}$

12 See Catherine L. Fisk \& Deborah C. Malamud, Thirty-Ninth Annual Administrative Law Issue: Administrative Law Under the George W. Bush Administration: Looking Back and Looking Forward: Article: The NLRB In Administrative Law Exile: Problems With Its Structure and Function and Suggestions for Reform, 58 DUKE L. J. 2013, 2016 (2009) ("For decades, academic and judicial critics of the Board have urged it to embrace rulemaking, especially for cases in which it contemplates overruling precedent."); see also id. at 2016 n.12 (citing Merton C. Bernstein, The NLRB's Adjudication-Rule Making Dilemma Under the Administrative Procedure Act, 79 YALE L.J. 571 (1970); James J. Brudney, Isolated and Politicized: The NLRB's Uncertain Future, 26 COMP. LAB. L. \& POL'Y J. 221 (2005); Samuel Estreicher, Policy Oscillation at the Labor Board: A Plea for Rulemaking, 37 ADMIN L. REV. 163 (1985); Cornelius J. Peck, The Atrophied Rule-Making Powers of the National Labor Relations Board, 70 YAle L.J. 729 (1960); Cornelius J. Peck, A Critique of the National Labor Relations Board's Performance in Policy Formulation: Adjudication and Rule-Making, 117 U. PA. L. REV. 254 (1968); Clyde W. Summers, Politics, Policy Making, and the NLRB, 6 SyracuSe L. ReV. 93 (1954); Ronald Turner, Ideological Voting on the National Labor Relations Board, 8 U. PA. J. LAB. \& EMP. L. 707 (2006); George W. Chesrow, Comment, NLRB Policymaking: The Rulemaking-Adjudication Dilemma Revisited in NLRB v. Bell Aerospace Co., 29 U. MiAMI L. REV. 559 (1975)).

13 Jeffrey Lubbers, The Potential of Rulemaking by the NLRB, 5 FIU L. REV. 411, 414 (2010) (citing Katie R. Eyer, Administrative Adjudication and the Rule of Law, 60 ADMIN. L. REV. 647, 649 (2008)).

14 Lubbers, supra note 13, at 415 (citing Richard K. Berg, Re-examining Policy Procedures: The Choice Between Rulemaking and Adjudication, 38 ADMIN. L. REV. 149, 163-64 (1986)).

15 Id.

16 Id.; see also Jeffrey Hirsch, Defending the NLRB: Improving the Agency's Success in the Federal Courts of Appeals, 5 FIU L. REV. 437 (2010). 
Rulemaking could have more subtle benefits as well. Only the more difficult fact-patterns reach the Board unsettled, and we know that bad facts often make bad law. Difficult fact patterns are rarely the best vehicle for announcing a new approach. ${ }^{17}$ Rulemaking would also be more democratic, providing the public greater notice and an opportunity to comment. ${ }^{18}$ Finally, as Estreicher has noted, rules would more clearly guide the General Counsel in determining when to issue complaints. ${ }^{19}$

The rulemaking solution, likewise, is not new. Estreicher has been advocating for this shift for decades. ${ }^{20}$ Lubbers's paper provides an excellent history both of scholarly support for rulemaking, dating as far back as 1961, and of the Board's equally longstanding resistance to this solution. ${ }^{21}$ Lubbers's discussion of the so-called obstacles to rulemaking - whether ossification, the Regulatory Flexibility Act or the Congressional Review Act - reveal that the policy and legal challenges to rulemaking can be overcome. ${ }^{22}$ Finally, and most obviously, the best evidence that these obstacles can be surmounted is the simple fact that almost every other federal agency relies on rulemaking despite these so-called obstacles.

So the question is this: if the NLRB is in decline in part because of its historic reliance on unpredictable, case-by-case adjudication, and if rulemaking can alleviate this unpredictability, then why has the NLRB been so reluctant to engage in rulemaking?

The initial answer, I argue, begins with the Board's early history. Joan Flynn traced this history well, in her 2000 article, A Quiet Revolution at the Labor Board: The Transformation of the NLRB, 1935-2000. ${ }^{23}$ The NLRB was modeled in part after the National Labor Board (NLB). The NLB had been set up as a representative body with an equal number of industry and labor representatives, along with a neutral chair charged with representing the public interest. The original 1935 bill establishing the NLRB contained the same structure. The original reference to partisan representatives, however, was replaced with "three impartial Government members," in response to a congressional determination that the NLRB should be an ad-

17 Id. at 5

18 Samuel Estreicher, Improving the Administration of the National Labor Relations Act Without Statutory Change, 5 FIU L. REV. 361 (2010) ("In essence, the regulated public would be told in advance which prior decisions the Board is interested in possibly reversing and would be asked to address specific questions and identify sources of information that would aid the agency.").

19 Estreicher, supra note 6, at 177.

20 See generally Estreicher, supra note 6.

21 See generally Lubbers, supra note 14.

22 Id.

23 See Joan Flynn, A Quiet Revolution at the Labor Board: The Transformation of the NLRB, 1935-2000, 61 Оніо ST. L.J. 1361, 1363-65 (2000). 
judicatory body more akin to a "labor judiciary" of neutrals as opposed to an NLB-like mediatory body of representatives.

This system worked well at first, as Presidents selected neutrals to serve on a labor judiciary. This began to change, Flynn showed, in the early 1950s - when President Eisenhower nominated Guy Farm, a management attorney, and Albert Beeson, a management industrial relations director. The Congress of Industrial Organizations (CIO) objected to these nominations on the grounds that they were management representatives as opposed to true neutrals. The CIO noted that on the union-side, no union lawyer had ever been appointed to the Board. The Senate minority also opposed confirmation, arguing that the Board had been conceived as a "quasi-judicial agency" with impartial as opposed to representative members.

The issue resurfaced a little more than a decade later when President Nixon nominated Edward Miller, a lawyer with 23 years of experience representing management. As Flynn explained, AFL-CIO President George Meany objected vigorously to Miller's nomination, noting again that organized labor had never sought the appointment of a union-side lawyer. ${ }^{26}$ The Senate, however, confirmed the nomination. ${ }^{27}$

The next time around, the AFL-CIO did not merely object. In 1983, when President Reagan sought to appoint management attorneys to the Board, AFL-CIO President Lane Kirkland wrote to then Senate Labor Committee Chairman Orrin Hatch:

In the past . . . we sought the appointment of individuals who ... had not been the agents of management or labor. It has been our considered position that this degree of forbearance is necessary in the interest of assuring both justice and the appearance of justice in a highly adversarial field. . . These nominations . . . are the final evidence that . . there will be no reciprocal restraint. I wish, therefore, to state that as a matter of practical self-protection we hereby renounce our prior positions in this regard. ... [A]ll the old rules are off. ... I would regard us as privileged to follow the same practice and to

24 Id. at 1364, n. 12 (citing Staff of Senate Comm. on Educ. and Labor, 74th Cong., Comparison of S. 2926 (73d Congress) and S. 1958 (74th Congress) $\S 3$ (Comm. Print 1935), reprinted in 1 Leg. Hist. of the NLRA).

25 Flynn, supra note 23 at 1374.

26 Meany wrote: "It would, of course, be both possible and proper to have a tripartite Labor Board, with members designated as representing the public, labor and management. . . However, the NLRB in this country is not set up on that basis. . . We believe . . that no one should be appointed to the Board from the ranks of labor or management, and that includes union lawyers and employer lawyers." Hearings on Nomination of Edward B. Miller, 91st Cong. 35 (1970) (statement of George Meany, President, American Federation of Labor and Congress of Industrial Organizations).

27 Flynn, supra note 23 at 1375-76. 
put forth partisans of that temper, if we again come into a position where we might be able to have some persuasive influence over an Administration.... ${ }^{28}$

Since then, Flynn explains - with some exceptions - NLRB Members have arrived at the Board with a lengthy history of representing either management or labor. ${ }^{29}$

This history helps explain why the Board, in contrast with most administrative agencies, has clung to its historical process of case-by-case adjudication. The Board early on established itself in the model of a labor judiciary. Board Members sit in panels of three, to hear appeals from ALJs. On occasion, when precedent is to be overruled, the Board sits en banc as a panel of five.

Like a court, the Board does not proactively reach out for issues. It has delegated prosecutorial authority to the General Counsel. Much like a common law court of appeals, the Board waits for cases to raise issues and announces new rules through caselaw.

The Board's internal structure reflects this quasi-judicial approach. Each Member has a staff of attorneys who function as law clerks. The Chair has an additional staff member to address administrative matters. The staffing is analogous to a court, where each judge has his or her own law clerks, with the Chief Judge having an additional clerk charged with administrative responsibilities.

This history helps explain why the Board's caselaw flip-flops so often. The NLRB quasi-judicial decision-making structure was adopted seventyfive years ago in response to Congress' intent that the Board operate as a labor judiciary. The NLRB's membership, by contrast, has strayed from this path. The NLRB today is comprised of Members who consider themselves quasi-representatives of labor or management with an occasional neutral. However, quasi-representatives continue to use the Board's seventy-five-year-old quasi-judicial decision-making infrastructure. As a result, Board caselaw oscillates, as Board Members reverse prior precedent in tune to the shifting balance of power between quasi-representatives for labor and management.

This early history and the quasi-judicial structure it produced, I believe, also present the principle obstacles to rulemaking. The Board lacks experience operating outside its quasi-judicial model. An example of this

28 Flynn, supra note 23, at 1389 (citing letter from AFL-CIO President Kirkland to Sen. Hatch (RUtah), Daily Lab. Rep. (BNA) No. 22, at E-1 (Feb. 1, 1983) and a press conference given by AFL-CIO President Kirkland).

29 See Flynn, supra note 23. 
structural challenge is the Board's only successful rulemaking. The Board's successful 1989 health care rule, as Professor Lubbers points out, was promulgated only after public hearings were held in Washington, Chicago, and San Francisco - during which the Board heard testimony from 144 witnesses. $^{30}$ The Board's reliance on multiple hearings, structured like a judicial adjudicative process, delayed and complicated the rulemaking process substantially. ${ }^{31}$ If modern agencies had to rely on similarly cumbersome procedures, the Code of Federal Regulations would be much shorter.

The Board again attempted rulemaking in the 1990s, this time unsuccessfully. ${ }^{32}$ Contemporaries were quick to cast blame, with some pointing to Congress and others to the rather outspoken Chairman who some argued overstepped and overreached. Then Chairman and now Stanford Professor Gould's own memoir offers insight into both the policy benefits of, and the Board's structural lack of preparedness for, rulemaking.

Rulemaking was peculiarly suited to another problem that had affected the Board since the Eisenhower administration. With each new president ... the Board's philosophy on major policy issues swing $[\mathrm{s}]$ in a new direction. ... I thought that rulemaking would diminish these rapid shifts. . . . It would thus strengthen the doctrine of stare decisis. . . . Rulemaking, because it would put the public on notice, would overcome the problem of lack of input I was simultaneously attempting to solve. ... And because a detailed justification for each rule would be provided, future Boards might be inhibited from wholesale reversals. ... ${ }^{33}$

Our efforts were not wholly successful because rulemaking . . . necessarily attracted a good deal of attention early in the process. This meant that pressure against a rule members of Congress did not like could be brought to bear before the Board made its final decisions. ....

What we had not foreseen ... was the fact that rulemaking, by its very nature, generates publicity. . . . By using rulemaking . . . we advertised what we were thinking of doing before we did it, thus inviting politi-

\footnotetext{
JefFrey S. LubBers, A Guide to Federal AgENCy RULEMAKING 129 (2006).

Id. at 312 .

Lubbers, supra note 13 , at 10 .

William B. Gould, IV, Labored Relations: LaW, Politics, AND the NLRB - A Memoir 72

34 Id. at $72-73$
} (2001) 
cal interference. ... [T] $[$ his kind of interference could stop the Board in the starting-block.

Adjudication, on the other hand, was a different matter. . . . We carefully released . . controversial decisions without any fanfare. In that case, it was a long time before anyone even noticed. Of course, when they did, there were hostile reactions, but by then the Board had already taken action and Congress had passed our budget. So the publicity came after the horse was out of the barn. In rulemaking . . the opposite was true. ${ }^{36}$

Chairman Gould's comments evoke several thoughts. One is that Chairman Gould and the Board were woefully unprepared for and inexperienced with rulemaking. To say that Chairman Gould did not anticipate publicity on an issue like a Beck rulemaking demonstrates the Board's naïvete. Chairman Gould certainly clashed with the Republicans in Congress, which undoubtedly brought pressure to bear regarding the Board's proposed rules. ${ }^{37}$ Agencies experienced with rulemaking would

35 Id. at 173.

36 Id. at 173-74.

37 Id. at 72 ("[Rule making] would thus strengthen the doctrine of stare decisis - a judicial principle to which I had expressed fidelity in responding to a question Senator Hatch asked me in my confirmation hearing. . . . Our efforts were not wholly successful because rule making, like oral arguments (and we held a record number of oral arguments), necessarily attracted a good deal of attention early in the process. This meant that pressure against a rule members of Congress did not like could be brought to bear before the Board made its final decision. This is what happened in connection with our rulemaking proposal on single-facility units when we brought it forward near the beginning of the Hundred and Fourth Congress in 1995. Several Board members were genuinely sympathetic to rule making and to the objectives of this proposal; but they also wanted to be reappointed and so were not immune to political pressure. And there was political pressure aplenty. The new Republican Congress wanted us, in Congressman James Talent's (R-Mo.) words, to "flip" as well as "flop" on the single-location cases. The Republicans clearly feared that this rule would expedite NLRB elections, facilitate union organizing, and promote recruitment of new union members (a prospect their patrons abhorred) - and that it would be difficult to reverse."); $i d$. at 172-73 ("The drumbeat of criticism continued and was eventually embodied in a rider to our 1996 appropriations bill. It precluded the expenditure of any funds on the proposed rule and ensured that the issue would be nothing more than a debating point during my term of office. The proposed rule on appropriate bargaining units appeared to dwarf, or at least diminish, congressional anger over our handling of "salting" cases (which involved employer retaliation against paid union organizers who were also employees) and use of Section 10(j) injunction actions. (The House Republicans had enacted a rider requiring a four-vote Board majority to authorize injunctions but it was not in the final bill.) In fact, the focus on rule making gave us somewhat greater discretion in the Section 10(j) arena. After all, there were only so many issues Congress could use to control us through the appropriations process - given the hostility of some senators (e.g., Specter) to legislation by appropriations rider. In the 1996 budget, rulemaking was the one "chit" House Republicans managed to cash in."); id. at 255 ("Obey had advised me well. I had indeed become the House Republicans' number one enemy. This status was hardly surprising, given the Republican view of the National Labor Relations Act, my confirmation difficulties, the policies I pursued, and the balanced relationship between labor 
have predicted and been prepared for a response like this. Although rulemaking typically triggers political pressure from all sides, agencies find paths through the omnipresent political thicket and enact rules.

Chairman Gould's comments also reveal a disturbing hostility to transparency and an unfortunate deference to institutional inertia. Rather than develop expertise in rulemaking, the Chairman's response to the challenges presented by a rulemaking was simply to return to the old way of doing things despite his own belief that this old, quasi-judicial approach, was flawed. It was simply easier to return to the Board's safe, historical, less transparent, adjudicatory decision-making system. And the Board has remained there ever since.

To engage in successful future rulemakings, the Board must first overcome this institutional inertia and adjust its internal structure so that it is prepared for the quasi-legislative act that is rulemaking. It should learn from other agencies and it should hire staff experienced with the specific challenges of rulemaking. The authority to hire Board staff and economic experts would facilitate rulemaking, as the Board's practice of eschewing internal experts and instead relying on amici - again a quasi-judicial tradition - presents a challenge to rulemaking. The Board, likewise, must be prepared to make the political, staffing, and budgetary commitments necessary to respond to the costs that will be exacted at first, as Congress and others again try tactics like those tried against Chairman Gould. The first rule in decades will not be easy for the Board to enact.

To my mind, however, this price is worth paying. Many of the criticisms leveled at the Board flow from the Board's tendency to use quasijudicial adjudication to announce quasi-legislative rules. Although technically legal, this reliance on adjudication as a mechanism to bypass the democratic pressure ancillary to rulemaking opens the Board to criticism, in part because key decisions read more like policy briefings than legal opinions.

During my time on the Board, I thought long about how Members should approach decision-making. In essence, I believe Members have both a quasi-judicial and a quasi-legislative role. When applying existing precedents to facts, there is little room for personal policy preference. Here, legal reasoning and stare decisis are at their strongest. Members have an obligation to remain neutral and to apply prior precedent. In those settings, I would often vote with then-Members Liebman or Walsh, to the consternation of some colleagues and some individuals of the labor bar.

and management I promoted during my tenure. The home stretch of my journey was, therefore, the most perilous and difficult part."). 
Sometimes, however, Members are called upon to re-examine the wisdom of a precedent. This requires Members to draws upon their role as administrative quasi-legislators, applying their expertise and their own policy preference. Reflective discretion to reconsider rules is an appropriate role for an executive appointee to an administrative agency. In these contexts, my inclinations likely diverge from the now-Chairman. In these quasi-legislative contexts, however, rulemaking is the preferred path.

Board Members know when they are wearing which hat. Take In re $I B M$, for example. In overruling Epilepsy Foundation, the majority wrote:

[We] conclude that the policy considerations supporting that decision do not warrant, particularly at this time, adherence to the holding in Epilepsy Foundation. In recent years, there have been many changes in the workplace environment, including ever-increasing requirements to conduct workplace investigations, as well as new security concerns raised by incidents of national and workplace violence.

Our consideration of these features of the contemporary workplace leads us to conclude that an employer must be allowed to conduct its required investigations in a thorough, sensitive, and confidential manner. This can best be accomplished by permitting an employer in a nonunion setting to investigate an employee without the presence of a coworker. $^{38}$

Here, the majority's decision was not based on law; it admits that Epilepsy offers an acceptable interpretation. Instead, the majority's decision to change caselaw was based on "policy considerations." Its reasoning was quasi-legislative.

In response, then-Members Liebman and Walsh wrote:

Chairman Battista and Member Meisburg acknowledge that the Board's decision in Epilepsy Foundation is 'a permissible interpretation of the Act,' but invoke 'policy considerations' for refusing to adhere to it, and Member Schaumber endorses those considerations. The decision to overrule a recent precedent, carefully reasoned and upheld in the courts, should be based on far more compelling reasons than our colleagues have articulated. ${ }^{39}$

I agree, in one sense, with Member Liebman. The decision should have been based on a fuller record. In fact, it should have been based on the type of record that would result from public notice and comment. I 
disagree, however, with Members Liebman and Walsh to the extent that they believe that the majority, acting as policy-makers, should not reach such a decision. As quasi-legislators, the majority had that right, much like the Liebman Board will have a right to reach an opposite conclusion.

Members Liebman's and Walsh's real criticism is not that the majority exercised its quasi-legislative right to change policy, but rather that the majority changed policy within an adjudicatory setting ill-suited to developing a fuller record that includes notice and comment. Their criticism is accurate, but until the Board is ready to engage in rulemaking in lieu of adjudication, their criticism is also misplaced.

Is the Board ready to engage in rulemaking in lieu of adjudication? Then-Member Liebman's minority dissent implies that it may be, yet nowChairman Liebman's majority Board may feel compelled to follow the safer, historical path of reversing prior precedent through adjudication. With this in mind, I would like to close with some unsolicited advice to my former colleague. To the Chairman, I respectfully urge the courage to follow what her predecessor, Chairman Gould, called a perilous path.

I hear that Chairman Liebman has some interest in rulemaking. I urge her courage because the value of rulemaking will be underappreciated by most. The labor bar, on all sides, benefits from the oscillation and obfuscation of the adjudicatory system. With each presidential cycle, both management and labor hire lawyers anew to seek or defend against the reversal of prior precedent. Likewise, some in the Board's hierarchy oppose rulemaking, as their traditional interests in quasi-adjudicative structures are threatened. The political pressures brought to bear on the first rulemaking will be substantial. Challenges in Courts of Appeals will ensue. Against this, the praise of a few law professors and even a few former Board Members will be a small shield.

In the end, however, rulemaking will enhance the legitimacy and relevance of the NLRB by more clearly delineating quasi-judicial functions (whether fact-finding or law-finding) from quasi-legislative functions. This will help stabilize Board law and restore public and judicial confidence in the agency. Rulemaking will bring the Board's seventy-five-year old structure into alignment with that of a modern administrative agency. Once accustomed to rulemaking, the Board will operate more smoothly as it aligns its structures with those of other agencies in the modern administrative state.

To the future minority, I would like to suggest rulemaking as well. I was speaking with a friend in the minority about my remarks today. He said rulemaking was a bad idea at this time. That is not a good reason to stop a good idea. Under that logic, there will never be a good time to im- 
prove operations at the Board, as someone will always be in the minority. Good governance should trump particular results.

The Board in 2010 is operating under a pre-World War II quasijudicial administrative agency model. Rulemaking is a better, more democratic, more stable, more transparent, and more modern path for quasilegislative enactments. Scholars, including those present at this symposium, have suggested other important changes that may likewise benefit the Board. The challenge we now face, as scholars and former and current Board Members, is how to move beyond the enumeration of policy advantages and focus on practical, structural changes that can support Board efforts to implement rulemaking and other suggested changes, assuming that the Board in fact chooses to change. Unless the Board modernizes its structure, I fear that in ten years, at the Board's eighty-fifth anniversary, we will be discussing the challenges faced by an even less relevant NLRB. 